THE KURUME MEDICAL JOURNAL Vol. 16, No. 1, 1969

\title{
EFFECTS OF PROPRANOLOL ON THE ISCHEMIC HEART MUSCLES IN DOGS
}

\section{HIRONORI TOSHIMA, TSUNETAKA MATOBA, HISASHI SHIMADA, RYOTARO TANAKA AND NOBORU KIMURA}

\author{
Third Department of Internal Medicine, \\ Kurume University School of Medicine, \\ Kurume, Japan
}

(Received for publication March 3, 1969)

Since a newer beta-adrenergic blockng agent, propranolol, was synthesized, many notable reports have appeared concerning the pharmacophysiologic properties and the clinical use during the past few years. However, the effects on the ischemic heart muscles have not studied using microelectrodes.

The present study was performed to investigate the electrophysiological effects of propranolol on the ischemic heart muscles in dogs with myocardial infarction.

\section{METHODS}

Adult mongrel dogs were anesthetized with thiopental sodium, $30 \mathrm{mg} / \mathrm{kg}$ intravenously and subjected to thoracotomy and ligation of the branches of the right coronary artery on the free wall of right ventricle. Ligation was carried out at a distance of approxymately $1 \mathrm{~cm}$ away from the right coronary groove which led to the ischemic lesions in the free wall of right ventricle. Of ten dogs, eight surviving "ischemic" ones were left alone for a week.

On the seventh day following operation, the heart was removed and the free wall of the right ventricle was disected, when its preparation was stored in an oxygenated Tyrode's solution $(\mathrm{pH}=7.3)$ at room temparature until ready for use. The muscle strip which was obtained from the free wall of right ventricle, measuring about $5 \times 12 \mathrm{~mm}$ in size, was mounted with the endocardial surface upwards on gum plate in a tissue bath of $100 \%$ oxygenated Tyrode's solution and held lightly by a small pin.

The muscle chamber had a final volume of $47 \mathrm{ml}$ Tyrode's solution which was

* This paper was presented at Kyushu section of Japanese Circulation Society in Kagoshima on June, 1968.

This work was supported by a research grant from the Japanese Ministry of Education. 
bubbled with $100 \%$ oxygen gas and maintained at $36^{\circ}( \pm 1)$. The level of the solution in the chamber was kept constant by an over-flow tube.

Transmembrane action potential, conduction time from stimulation to depolarization, the contractile tension and bipolar electrocardiogram were racorded simultaneously from the same cell in the endocardial layer throughout one experiment. The terminal Purkinje fibers were avoided. The preparation was stimulated at a constant rate of 96 per minute through a stimulator (Nihon Kohden MSE-3R). The recording system employed consisted of a cathode follower input DC amplifier (Nihon Kohden MZ-3B), DC amplifier (Nihon Kohden AD222) and a visigraph (San'ie Instrument Ltd. FR-201). The resistances of the recording pyrex glass ultramicroelectrodes filled with $3 \mathrm{M}-\mathrm{KCl}$ ranged from 5 to 16 megohms.

Propranolol (Inderal ${ }^{\mathrm{R} *}$ ) was applied directly to the muscle chamber, of which concentrations were $1 \times 10^{-6}, 10 \times 10^{-6}$, and $50 \times 10^{-6} \mathrm{~g} / \mathrm{ml}$, respectively. For each doses, five to seven experiments were performed and the muscle strips once used were thrown away.

\section{RESULTS}

\section{1) Resting Tension}

The muscle strip was stretched with an initial load of approximately $700 \mathrm{mg}$ by using a pin and a force displacement transducer (Nihon Kohden SBIT).

The resting tension was observed during twenty minutes after the administration of propranolol (Fig. 1).

In normal heart cells resting tensions were gradually increased except for the dose of $1 \times 10^{-6} \mathrm{~g} / \mathrm{ml}$, in which dose they resulted in a striking increase.

Ischemic Heart Cells

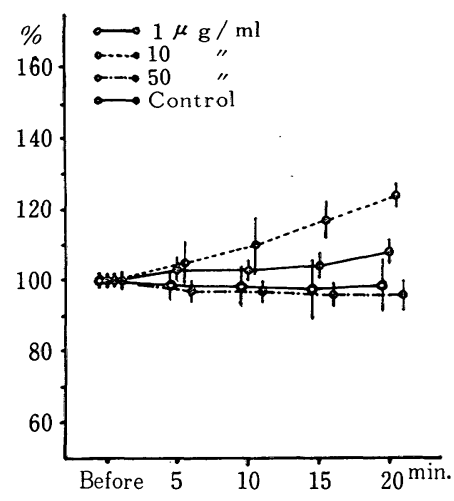

Normal Heart Cells

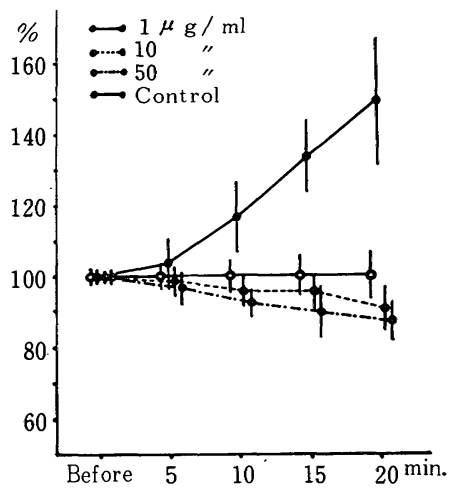

Fig. 1 Effect of Propranolol on Tension

\footnotetext{
* This drug was kindly supplied by Sumitomo Chemical Industries Limited, Osaka, Japan.
} 
A significant difference, $\mathrm{P}<0.01$, was observed between the effect of the dose, $1 \times 10^{-6} \mathrm{~g} / \mathrm{ml}$, and that of control at 20 minutes after the add. No administration of propranolol was in the control. In the ischemic heart cells the dose of $1 \times 10^{-6}$ and $1 \times 10^{-5} \mathrm{~g} / \mathrm{ml}$ were shown increasing resting tension and there was a significant alteration between the effect of $10^{-5} \mathrm{~g} / \mathrm{ml}$ and that of control $(\mathrm{P}<0.01)$.

Thus propranolol acted differently on normal and ischemic myocardial strips according to the dosis.

2) The Shape of Transmembrane Action Potential

Propranolol at the concentration of $5 \times 10^{-5} \mathrm{~g} / \mathrm{ml}$ effected so much on the shape of action potential as shown Fig. 2. The appearance of action potential was markedly depressed: the overshoot of the spike was disappeared and the plateau was also decreased. This phenomena were observed at the normal strips as much as the ischemic. At the concentration of $1 \times 10^{-6} \mathrm{~g} / \mathrm{ml}$ the overshoot was reduced considerably and the plateau was also slightly reduced. No significant change was between the two kinds of strips.

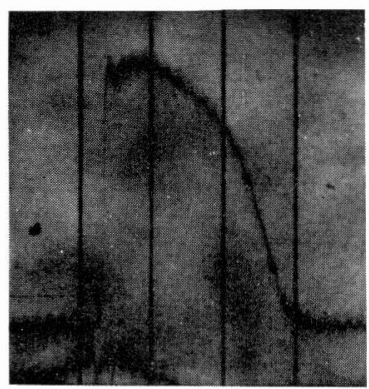

Before

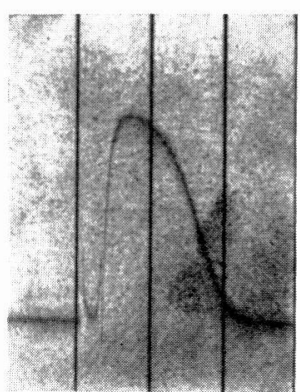

5 min. after

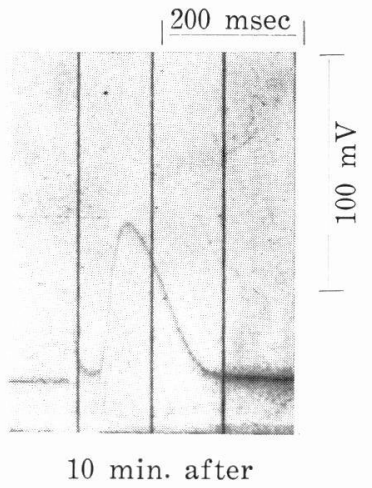

10 min. after

Fig. 2 Effect of Propranolol, $50 \mu \mathrm{g} / \mathrm{ml}$.

\section{3) Conduction Time}

The measurament of the conduction time was made at the distance between the stimulation and the begining of the depolarization. In the ischemic myocardial cells the conduction time exhibited retardation in proportion to the concentration of propranolol (Fig. 3). At the dose of $5 \times 10^{-5} \mathrm{~g} / \mathrm{ml}$ it delayed five times in comparison with controls.

4) Electrocardiogram of the Strips

The bipolar electrocardiograms taken from the ischemic strips used showed depressed ST segment (Fig. 4).

5) Histologic Findings

The degeneration was observed in all ischemic preparation: necrosis, neutrophil and small lymphocytes infiltration, fibroblastes and preliferation of blood vessels. 


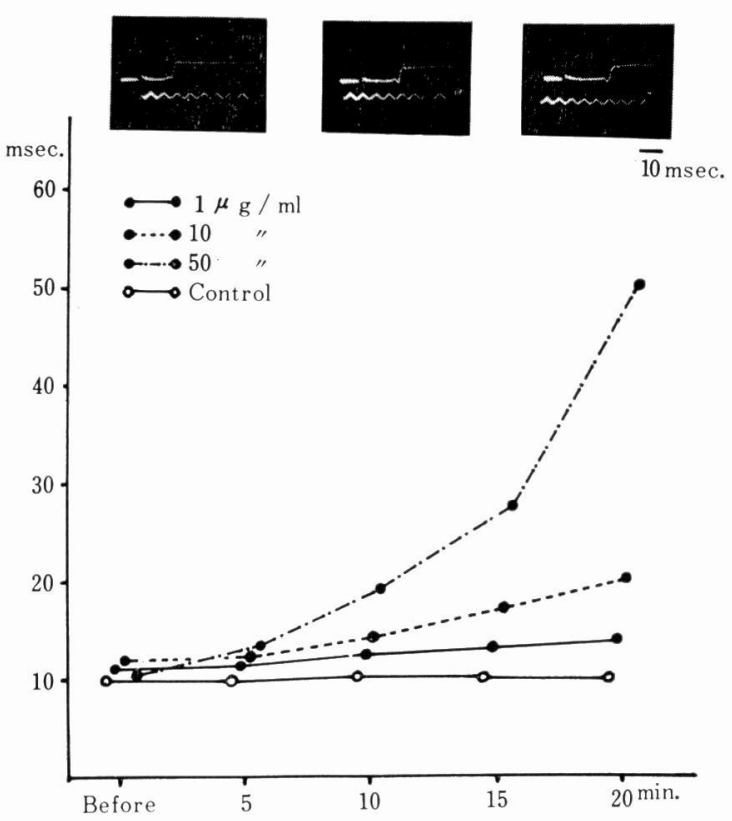

Fig. 3 Effect of Propranolol on Conduction Time.

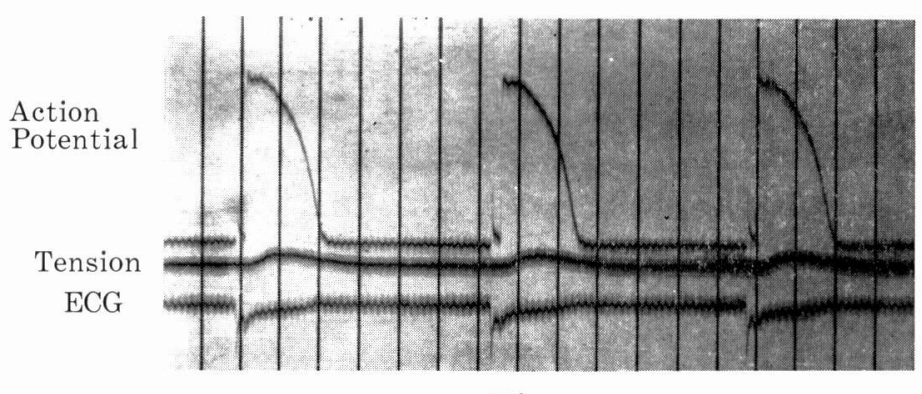

Fig. 4

\section{DISCUSSION}

Propranolol has been made a clinical application against arrhythmias, angina pectoris, hypertension and other diseases as a beta-blocking agent ${ }^{1 / 2)}{ }^{3)}$. In this experiment the effect of propranolol on the heart muscles in vitro was investigated using a microelectrode technique.

The isometric resting tension in vitro was increased in the concentration of $10^{-6} \mathrm{~g} / \mathrm{ml}$ in the intact strips and of $10^{-6}$ and $10^{-5} \mathrm{~g} / \mathrm{ml}$ in the ischemic ones.

In other dosis it was decreased. Dichloroisoproterenolol (DCI) reveals the positive inotropic tension in a small dosis, while in a large dosis it brings to react the reduction of inotropic tension ${ }^{4}$. This result may indicate that propranolol has the pharmacological properties like DCI. 
Ischemic strips make a different response to propranolol in comparison with the intact. Similar observation was made by Redding and Rees ${ }^{5}$ ) that in the experiment of myocardial oxygen consumption using ${ }^{133} \mathrm{Xe}$ clearance propranolol reacted differently on normal and ischemic myocardium. In the electron microscopic studies the myocardium of mice with propranolol showed degeneration of mitochondria in the affected myofibles and an almost universal increase in the length of the $I$ bands and sarcomeres ${ }^{6}$. These myocardial lesions were similar to that with hypoxia ${ }^{7}$. Vaughan Williams ${ }^{8)}$ described that propranolol seemed to be local anesthetics. These findings suggest that the affected myocardium with hypoxia causes dull response to propranolol, which requires large dosis to get as much as normal effects.

The present investigation was also found that the shape of action potential changed markedly : disappearance of the overshoot, prolongation of depolarization time, shortened plateau and suppression of appearance of action potential. Furthermore there was prolongation of conduction time. These observations agree with that of many investigators ${ }^{91}{ }^{10}{ }^{111}$. Shigenobu and associates ${ }^{9)}$ reported that the action of pronethalol was mainly due to depression of the active inward current carrier system. Hiejima and associates ${ }^{12}$ ) were observed that propranolol decreased the potassium content of the intracellular compartments. Thus the phenomena of action potential with propranolol would be considered to relate inhibition of $\mathrm{Na}$-carrier system and the content of intracellular potassium.

\section{SUMMARY}

We observed the electrophysiological effects of propranolol on the ischemic heart cells in dogs with myocardial infarction as compared with the intact ones. On the administration of a small dose of propranolol, the resting tension in creased in the intact cells more than in the ischemic ones. However a large dosis indicated the reduced resting tension. The action potential was remarkably suppressed in proportion to the concentration of propranolol.

The mechanism of action of propranolol was discussed, and it was suggested that propranolol had a certain action except well-known effects as a beta-blocking agent.

The authors wish to express their appreciation to Dr. H. Kitsukawa for hishistological guidance. 


\section{REFERENCES}

1) Symposium on Propranolol. Amer. J. Cardiol., 18, 345-487, 1966.

2) Epstein, S. E. and Braunwald, E. : Beta-adrenergic receptor blocking drugs. Mechanisms of action and clinical applications. New Eng1. J. Med. 275, 1106 \& 1175, 1966.

3) Shanks, R.G. : Propranolol in myocardial infarction. Lancet. 2, 788, 1967.

4) Shimamoto, K. : Pharmacology, P.351. Igaku-shoin Co. Lit., Tokyo, 1964.

5 ) Redding, V. J. and ReEs, J. R. : Myocardial vascular reactivity. Lancet, 1, 548, 1966.

6 ) Sun, S. C., Burch, G. E. and De Pasquale, N.P.: Histochemical and electron microscopic study of heart muscle after beta-adrenergic blockade. Am. Heart. J., 74, 340, 1967.

7) Martin, A. M., Hackel, E. B. and Kurtz, S. M. : The ultrastructure of zonal lesions of myocardium in hemorrhagic shock. Am. J. Path., 44, 127, 1964.

8) Vaughan Williams, E. M. : The Action of Beta-Receptor Blocking Agents on Cardiac Muscle, Int. Symp. on the Coronary Circulation and Energetics of the Myocardium, P. 118, Karger, Basel/New York, 1967.

9) Shigenobu, K., Kamiyama, A., Takagi, K. and Matsuda, K. : Membrane Effects of Pronethlol on the Mammalian Heart Muscle Fiber. Jap. Heart J., 7, 494, 1966.

10) Vaughn Williams, E. M. : Mode of Action of Beta Receptor Antagonist on Cardiac Muscle. Am. J. Cardial., 18, 399, 1966.

11) Sano, T., Suzuki, F., Sato, S. and Iida, Y. : Mode of Action of New Anti-Arrythmic Agents. Jap. Heart J. 9, 161, 1968.

12) Hiejima, K., Sakamoto, Y., Ootori, M. and Sano, T. : Influence of Antiarrhythmic Drugs on Potassium and Sodium Contents of Rat Myocardium. Jap. Circul. J., 32, 1211, 1968.

Fig. 1 Isometric resting tension of the intact and ischmic heart muscle. A small dose of propranolol enhanced resting tension, whereas a large dose reduced it.

Different response was observed between intact and ischemic heart muscle.

Open circle showed control.

Fig. 2 Effect of propranolol $50 \times 10^{-6} \mathrm{~g} / \mathrm{ml}$. See text for explanation.

Fig. 3 Bipolar electrocardiogram showed depressed ST segment in the ischemic heart muscle. Above traces were action potential, middle ECG and under contractile tension.

Fig. 4 Conduction time and repolarization time were delayed. 